\title{
ALIMENTOS TRANSGÊNICOS, ÉTICA E DIREITO PENAL
}

\section{Guilherme Guimarães Feliciano}

Doutorando em Direito Penal pela Faculdade de Direito da Universidade de São Paulo Juiz do Trabalho pela $15^{\text {a }}$ Região

Co-editor do Boletim do Instituto Manoel Pedro Pimentel

(Faculdade de Direito da Universidade de São Paulo)

Resumo:

O autor aborda o fenômeno da transgênese sob as luzes da Bioética e do Direito. Demonstra, por um lado, a aplicabilidade dos princípios de Bioética - trindade bioética — à questão dos alimentos transgênicos; por outro, ressalta a importância do princípio da prevenção no tratamento judicial do tema. Enfim, procede à exegese da Lei de Biossegurança (Lei n. 8.794/95), mormente em seus aspectos penais.

\begin{abstract}
:
The author studies the phenomenon of transgenesis according to Bioethics and Law. He also shows the applicability of the Bioethics' principles - bioethical trinity - in the question of transgenetic food, and emphasizes the importance of the principle of prevention in judicial treatment of transgenesis. At last, he proceeds the exegesis of Biosecurity Act (8.974/95), chiefly in its criminal aspects.
\end{abstract}

Unitermos: alimentos transgênicos; transgênese; bioética; princípio da prevenção; Lei n. 8.974/95.

Sumário:

I. Introdução; II. Bioética e Alimentos Transgênicos; III. O Princípio da Prevenção; IV. A Lei de Biossegurança (Lei n. 8.974/95). Implicações Penais; V Conclusão; Bibliografia 
I. Introdução.

A modernidade trouxe consigo, como herança inexorável, os influxos da técnica e da tecnologia, que no final do século XX espraiam-se indelevelmente por todos os setores do conhecimento humano. Com efeito, "nenhum período da história foi mais penetrado pelas ciências naturais nem mais dependente delas do que o século $X X$. Contudo, nenhum periodo, desde a retratação de Galileu, se sentiu menos à vontade com elas" ${ }^{11}$ No caso particular das ciências sociais, a necessidade recorrente de se buscar equacionamentos fora de seus quadros inspirava, em certa medida, sensação de impotência e complementaridade. Nada obstante, a compreensão e o regramento das relações sociais mostrava-se cada vez mais infactível à margem de uma abordagem ora econômica, ora biológica, ora matemática — ou, em síntese, técnica. Cuidava-se de uma imposição da realidade, vicejante na Economia - "a tecnologia com base em avançadas teoria e pesquisa científicas dominou o boom econômico da segunda metade do século $X X "$ - e por vezes revelada como um mister de sobrevivência, mormente em tema de biotecnologia - "sem a última palavra em genética, a Índia e a Indonésia não poderiam ter produzido alimentos suficientes para suas populações em explosão, $e$ no fim do século a biotecnologia se tornara um elemento importante tanto na agricultura quanto na medicina" ${ }^{2}$ Desse modo, o cientista social — incluso o jurista - houve por bem se resignar, convencido de que "a ciência não pode ser limitada por leis e a única forma de impedi-la de passar por cima de questões éticas é uma maior participação da sociedade no processo" ${ }^{3}$ De fato, assim o é.

Nesse passo caminharam as discussões de Bioética, envolvendo os aspectos éticos e jurídicos da manipulação genética, da clonagem, da reprodução assistida e da experiência científica em seres humanos, etc.: sem o aparato conceitual técnico, jamais poderiam ser bem conduzidas. A abordagem jurídica desses fatos, ditos tecnológicos, não prescinde da diagnose própria das respectivas ciências naturais (a tal ponto que se falou, em hipótese similar, no desenvolvimento de um direito tecnológico, definido como "o complexo de normas jurídicas que

1. Eric Hobsbawn, Era dos Extremos - O breve século XX (1914-1991), 2a ed., S. Paulo, Companhia das Letras, 1998, p. 504.

2. Idem, ibidem, p. 507.

3. Marcelo Gleiser, físico teórico, em palestra realizada no MASP (Folha de S. Paulo, 28.04.1999). 
disciplinam o objeto tecnológico, no processo de aplicação da tecnologia ao meio social").

Daí porque, para o enfrentamento de tema tão tormentoso e atual alimentação transgênica à luz do Direito (e particularmente do Direito Penal) - é de rigor optar-se pelo viés interdisciplinar.

II - Bioética e Alimentos Transgênicos.

$\mathrm{Na}$ introdução, dizíamos da conveniência de que uma abordagem bioética seja interdisciplinar. Essa observação tem guarida no próprio conceito de Bioética, conforme a diç̧ão de Juan Carlos Tealdi: síntese de conhecimento e ação multidisciplinar para responder aos problemas morais no vasto campo da vida e da área da saúde. E prossegue: "De um lado, trata-se de ter os fundamentos filosóficos, teóricos e metodológicos que podem unir abordagens normativas da medicina, o direito, a teologia e outros campos do conhecimento com a opinião da comunidade sobre essas questões. De outro, julgamentos profissionais e decisões em problemas clínicos sobre questões particulares são distintos daquelas abordagens que levam ao compromisso das instituições e, portanto, de outros grupos da sociedade em sua globalidade" 5

O estudo da Bioética tem se pautado, no curso dos anos, por três fundamentos ou princípios, oriundos da tradição anglo-saxã, usualmente identificados como "trindade bioética": a beneficência, a autonomia e a justiça. ${ }^{6}$ Para cada uma dessas características, há o enfoque individual (concernente à deontologia e à ética médica) e o enfoque coletivo (mais apropriado às ponderações que se seguirão, acerca da introdução dos produtos agrícolas transgênicos no mercado nacional).

O princípio da beneficência obedece ao modelo de Hipócrates do "bonum facere" sendo o mais antigo critério da ética médica. Significa fazer o bem, cuidar da saúde, favorecer a qualidade de vida. Não se admitem escusas, desde que o procedimento envolva o bem estar de seres humanos. No entanto, não é absoluto;

4. Walter T. Álvarez, Introdução ao Direito da Energia Nuclear, S. Paulo, Sugestōes Literárias, 1975, p. 27.

5. In manual de programação do II World Congress Bioetica, apresentação, p. 3.

6. Princípios éticos indiretamente positivados pela Lei n. 8.974/95, que os consagrou ao tipificar as figuras penais do art. 13. 
há, pelo menos, quatro fatores de identificação recente que o limitam: a necessidade de se definir o que é $o$ "bem" para o paciente ou para a sociedade; a não aceitação de paternalismos ocasionalmente dessumiveis do princípio; o critério da autonomia (infra); as novas dimensões da justiça na área da saúde (infra). ${ }^{7}$

O princípio da autonomia dá relevância à capacidade da vontade racional humana de fazer leis para si mesma. Ora adotado como critério ético, era originalmente uma categoria jurídico-política; "significa a faculdade de a pessoa governar-se a si mesma, ou a capacidade de se autogovernar, escolher, decidir, avaliar, sem restrições internas ou externas" ${ }^{8} \mathrm{O}$ princípio decorre, entre outras coisas, de certa desconfiança da autoridade e da competência técnica, incutida na sociedade civil; dessa maneira, a autonomia passa a ser o direito moral e legal dos pacientes — ou da sociedade - para deliberar segundo suas próprias convicções, sem restrições ou coerção, por mais benfazejas que sejam as intenções do médico, no âmbito individual, ou do administrador público, no âmbito coletivo. ${ }^{9} \mathrm{O}$ paciente $\mathrm{e}$ a comunidade deixam de ser meros objetos na relação com o médico ou com a administração pública, passando a atuar como sujeitos cognoscentes. As relações deixam de ser verticais, monárquicas, para assumir feições mais horizontais e democráticas. Impõe-se uma restrição ao princípio da beneficência, que privilegia a autoridade da decisão técnica emanada por quem de direito (o médico, na relação com seu paciente; ou, "in casu" a Comissão Técnica Nacional de Biossegurança, na relação com a sociedade civil).

O princípio da justiça, enfim, pretende que toda atenção, todo cuidado e todo sistema de saúde sejam justos, além de funcionais e eficientes. ${ }^{10}$ Subdivide-se em vários princípios menores, a saber: 1. o princípio da defesa da vida física, primeiro princípio imperativo ético do homem para consigo mesmo e com terceiros; une-se a ele o princípio da qualidade de vida, visando à perquirição de condições favoráveis à expansão e ao desenvolvimento razoável de qualquer ser humano; 2.0

7. Cfr. Fundamentos da Bioética, Léo Pessini \& Christian de Paul de Barchifontaine (orgs.), S. Paulo, Paulus, 1996, pp. 40 e ss.

8. Idem, ibidem, p. 40.

9. Opõem-se, nesse particular, o interesse público secundário - é dizer, o modo pelo qual os órgãos da administração vêem o interesse público - e o interesse público primário — o interesse do bem geral "de per se" (cfr. Renato Alessi, Sistema istituzionale del diritto amministrativa italiano, 1960, pp. 197-198).

10. Léo Pessini \& Christian de Paul de Barchifontaine, op. cit., pp. 42-48. 
principio da liberdade ou da responsabilidade, pelo qual todo procedimento bioético depende do consentimento da parte interessada - paciente ou comunidade - que assume, ao consentir, responsabilidade parcial pelas respectivas conseqüências; 3. o princípio da totalidade (ou terapêutico), que somente admite o perigo ou o menoscabo da integridade física ou da saúde humana se em contrapartida o sujeito agente acenar com a vantagem de um bem ainda superior; esse princípio tem sido de especial relevância, em termos de ética médica, nos casos de intervenção cirúrgica (mormente extirpações), esterilização terapêutica, transporte de órgãos e geneterapia; 4. o princípio da sociabilidade e da subsidiariedade - o primeiro compromete cada pessoa com a realização do bem estar dos semelhantes, culminando na doação de órgãos, no voluntariado assistencial e no surgimento de obras assistenciais; o segundo impele a comunidade a ajudar os mais necessitados e garante a livre iniciativa dos grupos que funcionam a favor dos mesmos. ${ }^{.1}$

Nesse contexto, urge inserir a questão da manipulação genética e dos alimentos transgênicos. Denomina-se engenharia genética (ou bioengenharia) a ciência da intervenção humana consciente nos mecanismos de síntese e/ou da linguagem da vida; envolve saberes oriundos da física, da química e da biologia, que aliados a técnicas específicas possibilitam a manipulação das moléculas de DNA e admitem a reforma, a reconstituição, a reprodução e a construção de formas de vida, que se destacam dentre tudo quanto existe na natureza por serem essencialmente novas (não-preexistentes no meio natural). ${ }^{12}$ Não por outra razão, Fátima Oliveira assemelhou-a, metaforicamente, ao sétimo dia da criação: às voltas com tais conhecimentos, os seres humanos de hoje desempenham, mais do que nunca, papel decisivo na evolução das espécies, de modo que, "desde sempre, todo dia é dia de criação" 13

11. Idem, ibidem, p. 46. No Brasil, o princípio da subsidiariedade é realizado por intermédio dos programas de assistência social (art. 194, caput, in fine, da Constituição Federal), voltada ao atendimento das necessidades básicas da população e "prestada a quem dela necessitar. Independe, portanto, de contribuição à seguridade social. Diferencia-se, assim, da Previdência Social, pois nesta há necessidade de contribuição para obter seus benefícios. (Sérgio Pinto Martins, Direito da Seguridade Social, $2^{\mathrm{a}}$ ed., S. Paulo, Atlas, 1993, p. 191).

12. Idem, ibidem, p. 138.

13. Fátima Oliveira, Engenharia genética: o sétimo dia da criação, p. 10. A autora é médica, diretora da União Popular de Mulheres do Estado de São Paulo e assistente do Programa Saúde Reprodutiva da Mulher Negra do CEBRAP. 
A incógnita ética da bioengenharia reside na coexistência instável de esperanças e temores. $\mathrm{O}$ estudo das manipulações genéticas traz consigo alvissareiras perspectivas de cura para inúmeras doenças, de síntese de medicamentos mais ágeis e eficazes e de uma capacidade virtualmente inesgotável de produção de alimentos. Dentro dessa derradeira perspectiva - que representa a superação tecnológica do paradoxo malthusiano ${ }^{14}$ - inserem-se os debates sobre os alimentos transgênicos. Por outro lado, a experimentação genética acena com a ameaça de desequilíbrio ecológico, diante do desconhecimento da força impactante do "novo" em meio à natureza "natural" ${ }^{15}$ Economicamente, os mercados são promissores na medicina, na agricultura e na pecuária; já hodiernamente, enquanto pende a questão ética, os lucros são consideráveis. Dentre as diversas aplicações possíveis do conceito, há quatro delas que têm recebido da comunidade científica atenção redobrada: a biotecnologia vegetal, que possibilitou o surgimento dos híbridos e transgênicos (nesse último caso, basicamente o milho, o tomate, a soja, a batata, o algodão e o trigo) e procura, a um tempo, tornar as plantações mais resistentes às pragas e às intempéries $\mathrm{e}$ incrementar-lhes o valor nutritivo; as fábricas biológicas de origem vegetal, é dizer, vegetais hídridos e/ou transgênicos capazes de sintetizar princípios ativos de medicamentos; a biotecnologia animal e os "animais-fábrica" aquela para potencializar a utilidade do animal (valor nutritivo das carnes e do leite, produção de peles e lãs, etc.) e esses para a produção de medicamentos; a inseminação artificial "in vivo" e "in vitro" A própria clonagem, trasladada da ficção científica para a realidade com o advento da ovelha Dolly, tende a se firmar como tema de predileção (ao menos no espaço acadêmico); é, em si mesma, um processo de reprodução assexuada por meio do qual são produzidas cópias de genes, células ou organismos. Não é propriamente engenharia genética, mas parte das mesmas bases epistemológicas; e, como assere Fátima Oliveira, a clonagem não é mais uma questão de técnica, mas uma questão puramente ética. A técnica, já a possuímos, como pôde a humanidade constatar em 18.10 .93 (bem antes do fenômeno Dolly), quando Jerry Hall e Robert Stillman, da Universidade George

14. "Malthus estabeleceu alguns principios em sua teoria que poden ser citados da maneira que se segue: $1^{\circ}$ princípio - 'Podemos estar certos de que, quando a população não é detida por obstáculos, duplica em cada vinte e cinco anos e cresce de período em periodo segundo uma progressão geométrica'. $2^{\circ}$ principio - 'Os meios de subsistência, nas circunstâncias mais favoráveis, nunca podem aumentar mais rapidamente do que uma progressão aritmética. (Melhem Adas, Panorama Geográfico do Brasil, $2^{\text {a }}$ ed., S. Paulo, Ed. Moderna, 1989, p. 122.

15. Léo Pessini \& Christian de Paul de Barchifontaine, op. cit., p. 141. 
Washington, tornaram públicos seus experimentos sobre clonagem de embriões humanos. ${ }^{16}$ Com relação às técnicas de modificação genética, a observação tem demonstrado que, a par das coisas novas e úteis, tem surgido outras, "monstruosas e inúteis" $^{17}$

A solução do impasse ético pressupõe, para alguns, o resgate da função social das ciências biológicas. Assim, o procedimento biotecnológico somente terá sentido se direcionado ao bem comum, olvidados os propósitos meramente especulativos e a curiosidade mórbida; haverá de respeitar, outrossim, direitos fundamentais como o direito ao próprio gene, a inviolabilidade do patrimônio genético humano e a liberdade reprodutiva, "proposições que provavelmente serão as grandes bandeiras dos direitos humanos no próximo milênio" 18

Daí a relevância da contextualização bioética da transgênese. Transgênese é o processo científico de transferência de genes de um organismo para outro, podendo-se dar entre animais, entre vegetais ou entre animais e vegetais; os organismos submetido à transgênese são ditos transgênicos. Até agora, a pesquisa da transgênese tem sido impulsionada sobremaneira pela avidez econômica organismos mais resistentes e nutritivos, por superarem a sobrevida de seus congêneres naturais e beneficiarem em tese a saúde do consumidor, engendram maior produtividade e estimulam o consumo público. Os cuidados com a biossegurança têm sido relegados a um segundo plano, mesmo porque não há um alinhamento internacional a respeito; na $5^{\text {a }}$ Conferência da Convenção da Biodiversidade das Nações Unidas, realizada em fevereiro de 1999 em Cartagena (Colômbia), as partes convenentes - 170 países - simplesmente não chegaram a um consenso sobre o conteúdo possível de um tratado internacional de biossegurança. Mas, ainda que à margem do Direito Internacional Público ou do próprio Direito Positivo nacional, cumpre às autoridades públicas informarem suas decisões com a principiologia bioética, "ex vi" do art. $4^{\circ}$ da Lei de Introdução ao Código Civil c/c art. 13 da Lei n. 8.974/95 (conquanto não caiba defini-los como

16. Entre nós, confiram-se a respeito a Resolução n. 196/96 do Conselho Nacional de Saúde ("Diretrizes e Normas Regulamentadoras de Pesquisas Envolvendo Seres Humanos") e as Instruções Normativas 08/97 ("Instrução Governamental sobre Manipulação Genética e Clonagem em Seres Humanos") e 09/97 ("Normas sobre Intervenção Genética em Seres Humanos") da CTNBio.

17. Idem, ibidem, pp. 142-147.

18. Idem, ibidem, p. 162. 
"princípios gerais de direito" os princípios éticos da autonomia, da beneficência, da responsabilidade e da prudência foram positivados pelo legislador através da Lei de Biossegurança; ${ }^{19}$ por conseguinte, devem ser ditos, hoje, princípios jurídicos específicos de um sedizente "direito da biogenética") ${ }^{20} \mathrm{E}$, nessa esteira, impende consignar o relevante papel a ser desempenhado pelo Poder Judiciário nacional, que poderá vir a estabelecer um padrão ético de admissibilidade a partir de jurisprudência iterativa, ainda que o legislador desconsidere o imperativo bioético. A prática tem demonstrado, a propósito, a hegemonia do Poder Executivo em matéria legislativa; e o Poder Executivo, no Brasil como em outros países, tem sido condescendente com os fautores da produção transgênica. Basta ver que, nos EUA, a partir de 1987, mais de três mil organismos geneticamente modificados tiveram sua liberação no ambiente autorizada. No Brasil, mais recentemente (setembro de 1998), a Comissão Técnica Nacional de Biossegurança decidiu regulamentar o uso comercial de uma variedade de soja (a Roundup Ready, resistente ao herbicida Roundup) desenvolvida pela empresa Monsanto, que assim obteve autorização governamental para o plantio.

19. De se consignar que, dentre os mencionados, o princípio da prudência e o princípio da responsabilidade foram cunhados pelo Direito Ambiental, enquanto que os demais são genuinamente bioéticos. Sobre os primeiros, ensina Paulo de Bessa Antunes (Direito Ambiental, Rio de Janeiro, Lumen Juris, 1996, pp. 24-26): "O Principio da Prudência ou da Cautela é aquele que determina que não se produzam intervençōes no meio ambiente antes de ter a certeza de que estas não serão adversas para o meio ambiente"; já o principio da responsabilidade visa a "impedir que a Sociedade arque com os custos da recuperação de um ato lesivo ao meio ambiente causado par um poluidor perfeitamente identificado", equivalendo ao célebre princípio do poluidor-pagador (princípio n. 16 da Declaração do Rio de 1992).

20. Cfr. Marcelo Dias Varella, "O novo direito da biogenética", in O Novo em Direito Ambiental, Marcelo Dias Varella \& Roxana Cardoso B. Borges (org.), Belo Horizonte, Del Rey, 1998, p. 273: "O novo direito da biogenética compreende várias linhas diversas, todas relacionadas com a biologia e o direito. Assim, deslacam-se a biossegurança, a propriedade intelectual sobre seres vivos, a bioética e a proteção do acesso aos recursos genéticos dos paises do terceiro mundo. Nem todos estes temas estão regulamentados pelo ordenamento jurídico brasileiro, sob a ótica do positivismo juridico e do monismo estatal, mas alguns sim (...)" Adiante, lê-se (pp. 286-287): "o novo direito da biogenética traz em seu conteúdo teórico-normativo uma série de novos institutos, conceitos e sujeitos de direito, além de novas concepções para os institutos preexistentes, frutos do avanço tecnológico e mesmo de novas necessidades do ser humano. Resta saber se estes novos institutos constituem apenas uma ampliação dos direitos preexistentes, ou se realmente são sinais da mudança paradigmática por que passa a sociedade." E conclui: "Não é com a criação de sujeitos coletivos de direito, indefinidos, com novos contratos de comércio internacional, ou com a consciência internacional da necessidade de cooperação entre os paises ricos e pobres, ou mesmo com alteração dos limites da propriedade, que se reconstrói um novo paradigma. Talvez, sim, com o fim do monismo estatal e com o biocentrismo, mas sob o nosso ponto de vista, embora haja indícios do fim do monismo estatal, o Estado ainda é predominantemente a principal fonte de leis no Ocidente e o antropocentrismo continua a ser a principal razão de se proteger a fauna e a flora, e a própria denominação 'antropobiocentrista' não deixa de ser antropocentrista. 
Nesse ínterim, cabe retomar os fundamentos da Bioética. Numa democracia representativa, a decisão da autoridade administrativa - na espécie os órgãos de fiscalização dos Ministérios, dentro de suas respectivas atribuições, com amparo no parecer técnico conclusivo da CTNBio (art. $7^{\circ}$ da Lei n. 8.974/95) — de autorizar a comercialização deve corresponder, ao menos em tese, à opção mais afinada com a realização do bem comum das gentes (já sopesados os aspectos econômicos, sanitários e humanitários). Nessa medida, tem força institucional, e haveria de prevalecer à mercê do princípio da benevolência. Mas, como visto, esse fundamento encontra limite no principio da autonomia, que acomete à sociedade civil a prerrogativa de discutir a premissa administrativa e de eventualmente recusar aos organismos transgênicos ingresso no mercado interno. Dessarte, a interferência do I.D.E.C. (Instituto Brasileiro de Defesa do Consumidor) e do Greenpeace, ao questionar perante o Judiciário a autorização governamental deferida à Monsanto, é perfeitamente legítima; significa implementar e resguardar, na "praxis" institucional, o princípio bioético da autonomia, valendo-se para tanto do mais clássico mecanismo de controle político das nações republicanas (o sistema dos "checks and balances" implícito no art. $2^{\circ}$ da Constituição Federal). Aliás, mais do que legítima, acertada: o Judiciário reconheceu-lhes razão, ao menos em sede de cognição perfunctória. De fato, a $11^{\text {a }}$ Vara da Justiça Federal de São Paulo proibiu, em liminar de 16.04.99, a liberação da soja Roundup Ready para consumo, antes de estudo prévio de impacto ambiental e da regulamentação de normas de biossegurança e rotulagem pelo governo. A Monsanto recorreu, mas o Presidente do E. Tribunal Regional Federal da $3^{\mathrm{a}}$ Região indeferiu o pedido de suspensão dos efeitos da liminar. Dessa maneira, a discussão ético-científica ganha corpo e guarida em nosso meio - ainda que perante as barras dos tribunais.

$\mathrm{Na}$ realidade, um segmento da CTNBio chegou a cogitar da possibilidade de que os produtos transgênicos fossem comercializados no Brasil sem rotulagem; tanto que, em reunião do dia 19.04.99, a Comissão não conseguiu chegar a um acordo sobre a posição brasileira a respeito da obrigatoriedade de rotulagem, a ser levada à Comissão do Codex Alimentarius das Nações Unidas. ${ }^{21}$ Essa pretensão de anonímia, como se viu, foi de plano rechaçada pela liminar concedida; afinal, negar ao consumidor essa informação, diante dos riscos alvitrados, seria violar o art. $6^{\circ}$ III, do Código de Defesa do Consumidor e malferir o princípio da autonomia, 
cerceando o direito de escolha da sociedade civil. Em síntese, dificilmente a CTNBio lograria patrocinar sugestão mais atentatória aos padrões da Bioética.

III - O Princípio da Prevenção.

Analisada sob prisma diverso, avulta ainda uma vez o acerto da intervenção judicial em comento. Dentre os princípios basilares do Direito Ambiental - em cujo bojo se haveria de inserir o pretenso "direito da bioegenética" - projeta-se vigorosamente o princípio da prevenção (ou da precaução, ${ }^{22}$ ou ainda da prudência), insculpido genericamente na Declaração do Rio sobre Meio Ambiente e Desenvolvimento de 1992 (n. 15) ${ }^{23}$ e positivado, "in specie" pelo art. $13, \S 3^{\circ}$ IV. da Lei de Biossegurança (que agrega ao respectivo tipo penal a idéia de respeito a princípios éticos, "tais como o princípio da responsabilidade e o princípio da prudência"). Consoante a melhor doutrina, a prevenção consiste em impedir a ocorrência de danos ao meio ambiente a partir da adoção de medidas apropriadas, ditas preventivas, antes da elaboração de um plano ou da realização de uma obra ou atividade; essa ação preventiva é uma ação antecipada e "a priori" que, após longo tempo, mostrou-se preferivel às medidas "a posteriori" (como a restauração ou a repressão, que somente intervêm após um atentado consumado contra o meio ambiente). ${ }^{24} \mathrm{Ou}$, no dizer de Leme Machado, "não é preciso que se tenha prova científica absoluta de que ocorrerá dano ambiental, bastando o risco de que o dano seja irreversível para que não se deixem para depois as medidas efetivas de proteção ao ambiente. Existindo dúvida sobre a possibilidade futura de dano ao homem e ao meio ambiente, a solução deve ser favorável ao ambiente e não ao lucro imediato — por mais atraente que seja para as gerações presentes" ${ }^{25} \mathrm{O}$

22. Alguns autores pretendem discrepar as duas expressões, contextualizando-as historicamente (a primeira contemporânea à Conferência de Estocolmo de 1972 e a segunda introduzida pela Declaração do Rio de 1992 - princípio 15) e divisando nessa última - "princípio da precaução" - maior amplitude, inclusive por prescindir de certeza científica para que sejam tomadas medidas preventivas em havendo risco de dano sério ou irreversível.

23. Principio n. 15: "De modo a proteger o meio ambiente, o principio da precaução deve ser amplamente observado pelos Estados, de acordo com suas capacidades. Quando houver ameaça de danos sérios ou irreversíveis, a ausência de absoluta certeza científica não deve ser utilizada como razão para postergar medidas eficazes e economicamente viáveis para prevenir a degradação ambiental" (negritamos). livre).

24. Cfr. Michel Prieur, Droit de l'environnement, $3^{2}$ édition, Paris, Dalloz, 1996, p. 70 (traduçāo

25. Paulo Affonso L. Machado, Estudos de Direito Ambiental, S. Paulo, Malheiros, 1994, p. 166. 
princípio da prevenção concretiza-se sobremodo pela exigência de estudos de impacto ambiental (no Brasil, o E.I.A./R.I.M.A. do art. $9^{\circ}$ III, da Lei n. 6.938/81) e pela existência de dispositivos de prevenção de riscos, unificados e reforçados. ${ }^{26}$

No caso em apreço, o risco de que a introdução indiscriminada de sementes transgênicas no meio ambiente pudesse ocasionar danos ambientais era inolvidável conquanto não houvesse, a respeito, "certeza científica" (como ainda não há). Ambientalistas e biotecnólogos alvitram uma série de riscos potenciais de suma gravidade, como a provocação de alergias e a danificação do sistema imunológico no curso da cadeia alimentar, a transmissão dos genes alterados a outras espécies com a geração de "super pragas" e a afetação orgânica de animais e insetos. ${ }^{27}$ Um estudo de Arpad Pusztai a respeito, posteriormente reiterado por um manifesto de vinte cientistas de diversos países, evidenciou danos no sistema imunológico, nos rins, no baço e nos intestinos de ratos alimentados por dez dias com batatas transgênicas. ${ }^{28}$

Andou bem, portanto, o Poder Judiciário. Mesmo à míngua de provas científicas sobre as conseqüências danosas da transgênese, reconheceu a dúvida e procedeu conforme o princípio da precaução: "in dubio, pro natura" Exigiu para a comercialização dos transgênicos, a um tempo, o estudo prévio de impacto ambiental e a regulamentação administrativa do tema, que deverá abarcar dispositivos de biossegurança e normas de rotulagem. Implementa-se, com aqueles dispositivos, o princípio bioético da beneficência (não causar dano); e, com essas normas, o princípio da autonomia (direito de opção). A judiciosa ação de cidadãos comuns, com o aval da Justiça, supre o relativo descaso administrativo e tende a concretizar a precaução enquanto princípio, nos moldes preconizados por MorandDeviller (supra).

26. Cfr. J. Morand-Deviller, Droit de l'environnement, Paris, ESTEM, 1996, p. 20, "in verbis": "Il s'agit d'une constante du droit de l'environnement. Il se concrétise principalement par l'exigence de l'étude d'impact écologique (...) et par des dispositifs de prévention des risques. unifiés et renforcés. Mas o autor lamenta que a legislação francesa tenha subordinado as ações ambientais preventivas à noção de "custo economicamente aceitável" ("coût économiquement acceptable"), arriscando-se a deflagrar uma submissão excessiva da prevenção ambiental a imperativos de ordem financeira.

27. Folha de S. Paulo, 22.04 .99 (p. 6, C-1).

28. Folha de S. Paulo, 13.02 .99 (p. 16, C-1). Pusztai foi desligado do Instituto Rowett, no Reino Unido, após fazer declarações públicas sobre o assunto. No Brasil, o cultivo da batata transgênica ainda não é permitido, mas ela pode estar presente em produtos importados. 
IV - A Lei de Biossegurança (Lei n. 8.974/95). Implicações Penais.

Com o escopo de regulamentar os incisos II e V do $\S 1^{\circ}$ do art. 225 da "Lex Legum" e de normatizar o uso de técnicas de engenharia genética e a liberação no meio ambiente de organismos geneticamente modificados, veio a lume a Lei $\mathrm{n}$. 8.974, de 05.01.1995, sob os auspícros do então Ministro da Justiça (e hoje Ministro de Supremo Tribunal Federal) Nelson Jobim. A lei contou com alguns vetos presidenciais, todos sugeridos pelo outrora Ministério da Ciência e Tecnologia, e teve origem no Projeto de Lei do Senado n. 114 de 1991, de autoria do ex-senador Marco Maciel. O Senado, no entanto, aprovou substitutivo apresentado pelo relator Francisco Rollemberg. Na Câmara dos Deputados, tal substitutivo, sob n. 2.560/92, foi distribuído para duas comissões temáticas (Seguridade Social e Família e Defesa do Consumidor, Meio Ambiente e Minorias), que avaliaram seu mérito, aprovandose a final substitutivo do relator da primeira comissão, deputado Sérgio Arouca. Esse substitutivo foi submetido ao plenário em regime de urgência, e recebeu duas emendas. A Lei em comento abrange oito atividades relativas aos organismos geneticamente modificados: construção, cultivo, manipulação, transporte, comercialização, consumo, liberação e descarte. A matéria relativa às patentes ou "cultivares" no caso dos vegetais, não foi deslindada por esse diploma. Diversamente da União Européia, que editou uma norma para a utilização confinada de organismos geneticamente modificados (Diretiva n. 90/219 da C.E.E.) e outra para a sua disseminação voluntária (Diretiva n. 90/220 da C.E.E.), a legislação pátria planificou a questão, abordando-a de forma unificada. Entre as definições do art. $3^{\circ}$ (seguindo a tradição conceitual dos diplomas legais que regulam modalidades de direito tecnológico), relevam as seguintes: organismo (inciso I): "toda entidade biológica capaz de reproduzir e/ou de transferir material genético, incluindo vírus, prions e outras classes que venham a ser conhecidas"; organismo geneticamente modificado ou O.G.M. (inciso IV): "organismo cujo material genético (ADN/ARN) tenha sido modificado por qualquer técnica de engenharia genética"; engenharia genética (inciso V): "atividade de manipulação de moléculas ADN/ARN recombinante" Não são considerados O.G.M. os organismos resultantes de técnicas que impliquem a introdução direta, num organismo, de material hereditário, desde que não envolvam a utilização de moléculas de ADN/ARN recombinante ou O.G.M., tais como fecundação "in vitro" conjugação, transformação, indução poliplóide e qualquer outro processo natural (parágrafo único do art. $3^{\circ}$ ). Para os fins 
da lei, portanto, não são organismos geneticamente modificados os célebres "bebês de proveta" ou os próprios organismos autoclonados, ex vi de seu art. $4^{0}$ IV Nada obstante, se a clonagem for processada a partir de células geneticamente modificadas, ${ }^{29}$ ou envolver reprodução assexuada de um O.G.M., então estará sob a égide da Lei n. 8.974/95.

Conclui-se, pois, que toda a matéria relacionada à alimentação transgênica (à exceção dos "cultivares") rege-se pela Lei n. 8.974/95. É que sementes são, por definição, grãos com potencial germinativo; são, portanto, organismos no sentido do art. $3^{0}$ I (entidade biológica capaz de reproduzir e/ou transferir material genético); e sementes transgênicas são as que têm seu material genético alterado - portanto, organismos geneticamente alterados, na forma do art. $3^{0}$ IV Ou seja: cuida-se de típico O.G.M.

$E$, nesse contexto, exsurge o estudo das increpações penais possíveis em tema de alimentação transgênica. Os tipos penais da Lei n. 8.974 - crimes contra a biossegurança - constam do art. 13; são ao todo cinco crimes, afora as formas qualificadas e o tipo culposo do $\S 4^{\circ}$ (com uma curiosa causa de aumento de pena no $\S 5^{\circ}$ caso a culpa revele-se na modalidade imperícia). Alberto Silva Franco considerou-os degradantes sob o ponto de vista técnico; mais que isso, "se fosse permitida uma expressão mais vulgar, caberia dizer que o art. 13 dessa lei é um verdadeiro 'besteirol' jurídico" ${ }^{30}$ Mas, bem ou mal, "legem habemus"; cumpre ao intérprete buscar o alcance e o significado dos preceitos increpantes, procurando

29. De se observar, por oportuno, que a Instrução Governamental sobre Manipulação Genética e Clonagem em Seres Humanos (I.N. n. 08/97 da CTNBio, publicada no D.O.U. de 31.07.97) encampa vedação administrativa aos experimentos de clonagem radical através de qualquer técnica de clonagem (art. $\left.2^{\circ}, \mathrm{I}\right) ;$ a clonagem radical é, justamente, o "processo de clonagem de um ser humano a partir de uma célula, ou conjunto de células geneticamente manipulada(s) ou não" (art. $1^{\circ}$, V). A clonagem simples, porém, não está proibida (processo básico de reprodução assexuada em humanos). Ademais disso, aquela vedação poderá ser questionada em sede judicial, tendo em vista o veto aos arts. $5^{\circ}$ e $6^{\circ}$ da Lei n. 8.974/95; com efeito, o diploma legal acabou por não estabelecer as atribuiçōes especificas da CTNBio, embora se reporte à Comissão por dezenove vezes. Sua "competência" foi traçada pelo art. $2^{\circ}$ do Decreto n. 1.520/95, incluindo o "estabelecimento de normas e regulamentos relativos às atividades e projetos relacionados a organismo geneticamente modificado (OGM)" Ocorre que: 1. o decreto do Poder Executivo não poderia ir além dos lindes explícitos da lei, sob pena de violaçāo do princípio constitucional da legalidade (art. $5^{\circ}$, II, da Constituição Federal); 2 . ainda que se o considere legal, a vedação à clonagem radical de seres humanos a partir de células não geneticamente manipuladas pode ser interpretada como regulação "ultra vires", tendo em vista que nesse caso o experimento não estaria envolvendo O.G.M. (e, portanto, estaria fora da "competência" estatuída pelo art. $2^{\circ}, \mathrm{V}$, do Decreto $\mathrm{n} .1 .520$ ).

30. Alberto Silva Franco, "Genética Humana e Direito", in Revista Bioética, 4 (1): 17-29, 1996. 
lhes salvaguardar a aplicabilidade - "commodissimum est, id accipi, quo res de qua agitur, magis valeat quam pereat" ${ }^{31}$ — até o ponto em que não colidam com a regra constitucional.

A sanção penal, enquanto "ultima ratio" somente é infligida em um Estado Democrático de Direito (art. $1^{\circ}$ caput, da Constituição Federal) quando bens jurídicos socialmente relevantes são brutalmente lesados ou expostos à ameaça de lesão. Cabe aferir, pois, a potencialidade lesiva da atividade biotecnológica. Com esse propósito, Paulo Freire Vieira ${ }^{32}$ procedeu a um percuciente mapeamento dos riscos biotecnológicos, ao qual passamos a nos reportar. Para o autor, são os seguintes os "aspectos mais controvertidos que cercam a percepção atual do problema dos riscos biotecnológicos pelas comunidades científicas no contexto internacional": 1. riscos sobre o meio ambiente e sobre a saúde das populações - 0 temor advém da proliferação das técnicas de engenharia genética e da disseminação descontrolada de O.G.M. no entorno ambiental, antes mesmo que a capacidade humana de avaliação dos efeitos possíveis consolide-se do ponto de vista políticoinstitucional; de outra parte, vários autores julgam que as chances de alteração das funções ecossistêmicas em face daquela disseminação são reais, além do que o ideal de obtenção de espécies vegetais e animais mais resistentes pode ter um efeito perverso, a saber, a intensificação dos índices atuais de consumo de pesticidas e herbicidas altamente nocivos; 2. implicações sócio-econômicas negativas da difusão de biotecnologias - as inovações biotecnológicas, cuja pesquisa e implementação demandam numerário considerável, recrudesceriam ainda mais a hegemonia das grandes corporações transnacionais, com criação de monopólios de "know-how" e elevação de preços no setor agroalimentar, em detrimento das grandes massas de pequenos agricultores pobres nos países do hemisfério sul; 3. dimensão éticopolítica do poder de ingerência humana na relação homem-natureza — habilitada a criar formas vivas dotadas de características inéditas, impactando a própria dinâmica evolucionista, a humanidade revigora o projeto cartesiano de tornar o homem 0 senhor e dono da natureza; a criação de O.G.M. nas esferas vegetal e animal é pressentida como a antecâmara daquilo que provavelmente ocorrerá, no futuro, em

31. Ou "prefira-se a inteligência dos textos que torne viável o seu objetivo, em vez da que os reduza à inutilidade" (Juliano, apud Digesto, $34,5,12$ ).

32. Paulo Freire Vieira, "Erosão da Biodiversidade e Gestão Patrimonial das Interações Sociedade-Natureza - Oportunidades e Riscos da Inovação Biotecnológica", in 'O Novo em Direito Ambiental', op. cit., pp. 225-265. 
nível humano (otimização artificial do ser humano); ${ }^{33} 4$. critérios de regulação jurídica da biotecnológica - discute-se o modelo de legislação ideal para a disciplina e o monitoramento de processos e produtos tecnológicos, os riscos sociais aceitáveis, os atores mais adequados para a regulação jurídica da biossegurança e a forma de solução de controvérsias. Riscos, portanto, os mais diversos; todavia, dentre todos, o legislador brasileiro apenas considerou como penalmente relevantes os riscos daquela primeira categoria (sobre o meio ambiente e a saúde humana). Compreende-se: o risco macroeconômico não pode ser debelado, senão por força de lei que obrigue as transnacionais a compartilhar seu "know-how" com os agentes menos expressivos do mercado; e, ainda assim, remanesceria o problema da disponibilidade econômica para implementação das técnicas. Como o Brasil não possui tal lei — que, ademais, não obrigaria empresas sediadas noutros países - 0 tratamento penal (já na seara do Direito Penal Econômico e Concorrencial) seria absolutamente inócuo. Ao problema ético-político já nos ativemos no tópico anterior; de natureza mais moral que jurídica, esse problema envolve sobretudo a tomada de atitude por parte dos interessados e das autoridades públicas. Apesar das hesitações, a CTNBio tem procurado estabelecer limites concretos para refrear os exageros e, particularmente, a algenia experimental (I.N. n. 08/97). A desobediência a essas normas administrativas enseja sanções administrativas, civis e quiçá penais, conforme o grau de lesividade atual ou potencial da conduta. Enfim, os riscos ligados à regulação jurídica da temática envolvem a discricionariedade legislą̧iva, acometida constitucionalmente ao Poder Legislativo e irrenunciável, indelegável e incensurável juridicamente (exceto em casos de inconstitucionalidade formal ou material); não comportam responsabilidade penal. Restava ao legislador, então, os riscos mais palpáveis: lesão ou ameaça de lesão ao meio ambiente ecologicamente equilibrado e/ou à saúde pública.

Nesse diapasão, identifica-se a objetividade jurídica dos tipos penais do art. 13 da Lei n. 8.974/95: em primeiro plano, a biossegurança, que definimos como a estabilidade das funções ecossistêmicas, com a conseqüente incolumidade da vida e da saúde do homem, dos animais e das plantas, bem como do meio ambiente (cfr. art. $2^{\circ}$ caput, in fine, da Lei n. 8.974). A noção de biossegurança não

33. É o ideal da algenia, no neologismo de J. Rifkin (Algeny, New York, Viking, 1984, pp. 17-18), apud Paulo Freira Vieira, op. cit.: "A meta final consiste na criação tecnológica de um organismo perfeito e o 'estado áureo' equivale ao estado de eficiência otimizada. A natureza é vista como uma ordem hierárquica de sistemas vivos dotados de eficiência crescente." 
admite assimilação divorciada das próprias condutas increpadas em sua homenagem: à diferença da conduta do homicida, que põe em risco a vida de uma ou mais pessoas determinadas, as condutas do art. 13 ameaçam todo o entorno ecossistêmico (incluindo vida humana, vegetal, animal e respectivas interações); e à diferença dos crimes de perigo comum (arts. 250 usque 259 do Código Penal) ou do próprio crime de poluição (art. 15 da Lei n. 6.938/81, com a redação da Lei $n$. 7.804/89), as figuras penais do art. 13 - conquanto também apresentem perigo para um número indeterminado de pessoas (e, mais que isso, para os animais e vegetais, como no art. 15 da Lei n. 6.938, além do próprio meio ambiente como sistema interativo de todos esses fatores) - são particularmente censuradas por encerrarem procedimentos biotecnológicos cujos desdobramentos não estão sob o integral domínio da ciência oficial. Num segundo plano, surgem objetividades jurídicas secundárias: a vida, a integridade física e a saúde de seres humanos determinados (art. 13, incisos II, $\S \S 1^{\circ} 2^{\circ}$ e $3^{\circ}$; V. $\S \S 1^{0} 2^{0}$ ou $3^{\circ}$ ), além do meio ambiente ecologicamente equilibrado (art. 225, caput, da Constituição Federal). Na verdade, todo crime contra a biossegurança lesiona ou expõe à ameaça de lesão o meio ambiente; por conseguinte, todo crime contra a biossegurança é, necessariamente, um crime ambiental (admitindo, nos casos omissos, a aplicação analógica "in bonam partem" da Lei n. 9.605/98).

Os crimes contra a biossegurança são em geral crimes de perigo, entendidos como "os que se contentam com a probabilidade de dano"; perigo, aliás, do tipo abstrato, pois "a lei o considera resultante de certas ações, baseada em regras ditadas pela experiência ou pela lição dos fatos" - e, na hipótese em comento, baseada no princípio da precaução. Há, pois, presunção de perigo, que não precisa ser investigado e provado em cada caso concreto. ${ }^{34}$ Já as formas qualificadas (incisos II, $\S \S 1^{\circ} 2^{\circ}$ e $3^{\circ}$ e V. $\$ \S 1^{\circ} 2^{\circ}$ ou $3^{\circ}$ ) correspondem, enquanto tipos penais autônomos, a crimes de dano, assemelhados às lesões corporais, ${ }^{35}$ de se

34. Os conceitos são de Magalhāes Noronha, Direito Penal, v. 1, $5^{2}$ ed., São Paulo, Saraiva, 1968. pp. 106-107.

35. Cfr. Maria Celeste Cordeiro Leite dos Santos, O Equilíbrio de um Pêndulo. Bioética e a Lei: Implicações Médico-Legais, tese apresentada ao Concurso de Professor Titular do Departamento de Medicina Forense e Criminologia da FDUSP, S. Paulo, 1997, p. 200: "Os $\$ \S 1^{\circ}$, $\S 2^{\circ}$ e $\$ 3^{\circ}$, desta lei [8.974/95], reproduzem o crime do art. 129 - Lesōes Corporais - $\$ 1^{\circ}, \S 2^{\circ}$ e $\S 3^{\circ}$ (em parte) do Código Penal. O crime de lesão corporal é definido como ofensa à integridade corporal ou saúde. Isto é, como todo e qualquer dano ocasionado à normalidade funcional do corpo humano, quer do ponto de vista fisiologico, analômico ou mental. " 
falar, então, em crimes pluriofensivos, ${ }^{36}$ pois malferem mais de um bem jurídico relevante (a biossegurança $e$ a integridade física, a saúde ou a vida de outrem).

Com relação aos alimentos transgênicos, não têm maior pertinência os incisos I (crime de manipulação genética de células germinais humanas), II (crime de intervenção em material genético humano "in vivo"), III (crime de produção, armazenamento ou manipulação de embriões humanos destinados a servirem como material biológico disponível) e IV (crime de intervenção "in vivo" em material genético de animais), exatamente porque a transgênese, nesse caso, é feita em material genético de vegetais (sementes), e não em material humano ou animal. Já a figura típica do inciso $\mathrm{V}$ - crime de liberação ou de descarte no meio ambiente de O.G.M. em desacordo com as normas estabelecidas pela CTNBio e constantes na regulamentação da Lei n. 8.974/95 - aplica-se, em tese, à hipótese sob comento (desde que, evidentemente, se possam individualizar condutas típicas de pessoas físicas, visto que a regra do art. $3^{0}$ da Lei n. $9.605 / 98$ - responsabilidade penal de pessoas jurídicas - não pode ser estendida analogicamente aos crimes contra a biossegurança). A pena cominada é de reclusão, de um a três anos; se da conduta resultar lesões corporais leves, perigo de vida, debilidade permanente de membro, sentido ou função, aceleração de parto, dano à propriedade alheia ou dano ao meio ambiente, o infrator incorre na figura qualificada do $\S 1^{\circ}$ à qual se comina pena de reclusão de dois a cinco anos. E se a conduta resultar em incapacidade permanente para o trabalho, enfermidade incurável, perda ou inutilização de membro, sentido ou função, deformidade permanente, aborto, inutilização da propriedade alheia ou dano grave ao meio ambiente, a pena é de reclusão de dois a oito anos (figura qualificada do $\left.\S 3^{0}\right)$. Se, enfim, ocasionar a morte de alguém, a pena é de reclusão, de seis a vinte anos (figura qualificada do $\S 3^{\circ}$ ). O tipo básico é de perigo abstrato, enquanto que as formas qualificadas são pluriofensivas e reclamam a verificação de dano.

Trata-se de crime de mera desobediência, que se consuma com a liberação ou o descarte no meio ambiente de O.G.M. em desacordo com o regramento administrativo. Essa é, aliás, uma característica recorrente dos delitos ambientais, que passam a integrar um Direito Penal secundário, de ordenação administrativa. Confira-se o magistério de Paulo José da Costa Jr. ${ }^{37}$

36. Cfr. Damásio de Jesus, Direito Penal, v. 1, $15^{a}$ ed., S. Paulo, Saraiva, 1991, p. 192: "São os que lesam ou expõem a perigo de dano mais de um bem jurídico. Ex.: latrocínio (CP, art. 157, $\S 3^{\circ}$, 'in (ine'), em que há ofensa à vida e ao patrimônio.

37. Paulo José da Costa Jr., Direito Penal Ecológico, Rio de Janeiro, Forense Universitária, 1996, pp. 86-87. 
"Partindo das dificuldades sabidas que encontra o legislador penal para delimitar o âmbito e a intensidade da tutela a ser emprestada aos bens ambientais, sugerese que a proteção do ambiente seja confiada principalmente à autoridade administrativa, a quem cabe a obrigação de regulamentar os fatores poluentes, de conceder autorizações para o exercício de atividades perigosas, de impor limitações, cautelas e proibições com relação a elas. $O$ direito penal viria a desenvolver a função secundária de punir a violação de prescrições administrativas. $O$ crime ecológico então consistiria em mera desobediência aos preceitos da autoridade estatal competente em disciplinar o uso dos recursos ambientais. Semelhante sistema garantiria uma tutela imediata dos bens ecológicos, mas não direta. Essa seria ofertada pelo direito administrativo, enquanto o conteúdo do ilícito típico - a lesão-tipo — do crime ecológico viria a exaurir-se na inobservância a prescrições formais.

Tal panorama acomoda-se com tranqüilidade ao elenco de crimes contra a biossegurança em geral e à descrição típica do crime do art. $13, \mathrm{~V}$, em particular. A tutela imediata da biossegurança é sempre de ordem administrativa (pautada, "in casu" por normas estabelecidas pela CTNBio e constantes da regulamentação da Lei n. 8.974/95); para garantir a observância dos preceitos administrativos, intervém o Direito Penal através da incriminação de lesões-tipo que, na realidade, não pressupõem resultado naturalístico. O recurso à remissão, outrossim, caracteriza o comando do inciso V como norma penal em branco: para integrar o tipo penal, o julgador deverá reportar-se a outras normas jurídicas, regulamentares ou administrativas. Na realidade, a Lei n. 8.974 não tem, propriamente, um regulamento; mas se editou o Decreto n. 1.520 de 12.06.95, que acabou por lhe fazer as vezes. Esse decreto "dispõe sobre a vinculação, competência e composição da Comissão Técnica Nacional de Biossegurança - CTNBio, e dá outras providências"; ao dispor sobre as "competências" da CTNBio, acenou com o 
cabedal de exigências administrativas que podem preceder a autorização para liberação ou descarte de O.G.M. no meio ambiente (emissão de Certificado de Qualidade em Biossegurança para que as instalações possam funcionar, elaboração de EIA/RIMA, etc.). Se os organismos geneticamente modificados forem liberados ou descartados sem que as instalações estejam funcionando regularmente, ou sem que as determinações da CTNBio sejam acatadas (sejam elas gerais, para todos os projetos que envolvam O.G.M., ou particulares, para aquele projeto específico), o responsável poderá ser denunciado, processado e condenado por incorrer na conduta típica do art. 13, V. e também pelos danos que se seguirem. Assim então, "ad exemplum" se a Monsanto iniciasse em solo brasileiro a plantação de soja transgênica — modalidade de O.G.M., como se viu — à revelia da CTNBio ou em desacordo com as suas especificações, seria de rigor a increpação; responderiam pela infração penal todas as pessoas físicas que houvessem participado diretamente do ato deliberativo, por presumivelmente conhecerem a legislação de biossegurança (art. 21, $1^{\mathrm{a}}$ parte, do Código Penal); para os executores (plantadores e ceifeiros, e.g.), leigos completos, e porque a biossegurança não é um bem jurídico profano, ${ }^{38}$ melhor seria reconhecer-se o erro de proibição, escusável ou não, conforme as circunstâncias (art. 21, $2^{\mathrm{a}}$ parte, do Código Penal). Observe-se que, nesse passo, não se haverá de falar em inconstitucionalidade ou ilegalidade das exigências da CTNBio, já que houve expressa referência a essa regulação no corpo do tipo penal (cfr. nota 29).

Quanto às formas qualificadas, a opção do legislador pela técnica descritiva é elogiável. Poderia ter simplesmente se reportado aos parágrafos do art. 129 do Código Penal, ou ainda referir a denominação doutrinária (lesões graves no caso dos incisos II e V. $\S \S 1^{\text {os }}$ e lesões gravíssimas no casos dos incisos II e V. $\S \S$ $2^{0 s}$ ); mas, se assim procedesse, acabaria gerando perplexidades, seja pela má técnica, seja pelas divergências da doutrina. $\mathrm{O}$ critério descritivo, conquanto mais trabalhoso, é amiúde mais adequado.

A conduta de liberar pressupõe a perpetuação do interesse no objeto material, mesmo após o contato com o meio externo. Assim, se há plantio, transporte, comercialização ou consumo, há liberação. Já o descarte pressupõe rejeição; o O.G.M. passa a ser "res derelictae" (coisa abandonada). É criminoso,

38. Bens jurídicos de conhecimento vulgar, reconhecidos por toda a humanidade civilizada (vida, integridade física, honra, etc.). 
portanto, o depósito ou eliminação de O.G.M. como rejeito ou lixo, sem observância dos ditames administrativos de biossegurança. ${ }^{39}$

Como explicitado alhures, a ameaça ou o atentado à biossegurança atingem, invariavelmente, o meio ambiente ecologicamente equilibrado enquanto objetividade jurídica. Assim, o crime do art. 13, V. representa indubitável perigo ambiental abstrato. Além do perigo, contudo, pode haver dano efetivo à propriedade alheia ou ao meio ambiente; nesse caso (e conforme o elemento subjetivo que informou a conduta, como se dirá adiante), o infrator poderá responder pela forma qualificada do $\S 1^{\circ}$ (alínea "e" ou " $f$ " — danos simples), com pena de dois a cinco anos de reclusão, ou ainda pela forma qualificada do $\S 2^{\circ}$ (alínea " $f^{\prime \prime}$ ou " $g$ " se houver inutilização da propriedade alheia ou dano grave ao maio ambiente), com pena de dois a oito anos de reclusão. Inadmissivel, porém, a condenação cumulativa por crime de dano comum (art. 163 do Código Penal) ou por crime de poluição (art. 15 da Lei n. 6.938/81), respectivamente: a dúplice condenação deflagaria odioso "bis in idem"

Em caso de morte, a pena é de seis a vinte anos de reclusão (pena mínima superior à do $\S 3^{0}$ do art. 129 do Código Penal, que é de quatro anos — 0 que demonstra uma ligeira precedência axiológica da biossegurança em relação à integridade física individual, na concepção do legislador de 1995).

Quanto ao elemento subjetivo, tanto a forma básica quanto as qualificadas são dolosas, admitindo tanto o dolo direto quanto o indireto na modalidade eventual (não se imagina hipótese razoável de dolo alternativo, aqui). 0 resultado que agrava especialmente a pena, porém, deve ter sido causado culposamente (art. 19 do Código Penal), já que o Direito Penal da culpa, de alicerce constitucional, não se compraz com a responsabilidade penal objetiva. Se a causação do resultado foi dolosa, o agente não responderá pela forma qualificada, mas pela forma básica do inciso $\mathrm{V}$ em concurso formal com o delito material doloso configurado (lesões corporais graves ou gravíssimas, dano simples ou qualificado, delito de poluição ou algum dos crimes ambientais da Lei n. 9.605, aborto, homicídio). Dessume-se, então, que as figuras qualificadas do inciso $\mathrm{V}$ (assim como as do inciso II) do art. 13 são preterdolosas - dolo no antecedente, culpa no conseqüente.

39. Cfr., no mesmo sentido, Paulo Affonso Leme Machado, op. cit., p. 757. 
$\mathrm{O} \S 4^{\circ}$ prevê crime de perigo culposo, na forma do art. 18, parágrafo único, "a contrario sensu" do Código Penal. Previsão "sui generis" pois os delitos culposos são em geral delitos de dano (vide art. 18, II, do C.P.: "Diz-se o crime (...) culposo, quando o agente deu causa ao resultado por imprudência, negligência ou imperícia"). Ou, na lição de Damásio de Jesus:" "Sem o resultado não há falar-se em crime culposo. Neste caso, ou a conduta inicial constitui infração em si mesma ou é um indiferente penal" Mas, na espécie do art. $13, \S 4^{\circ}$ da Lei n. 8.974, a conduta não tem resultado naturalístico; há apenas lesão jurídica, por vulnerada a objetividade jurídica (biossegurança). E ainda assim há o delito, informado por culpa nas modalidades imperícia ou negligência. Inovou, pois, o legislador.

$\mathrm{O} \S 5^{\circ}$ introduz interessante causa de aumento de pena para o crime culposo do parágrafo anterior (o que é, também, pouco encontradiço em Direito Penal), desde que a culpa se revele na modalidade imperícia ("in verbis": "se o crime resultar da inobservância de norma técnica de profissão"). De forma inédita, o legislador considerou mais censurável uma das modalidades de culpa "stricto sensu" - justamente a imperícia, que noutros países foi abolida como modalidade didática autônoma de culpa, restando absorvida pela negligência. Esse destaque reservado à imperícia poderá, em verdade, tornar-se sintomático nas searas dō Direito tecnológico, diante da necessidade de que atuem, em tais setores, pessoas cada vez mais capacitadas e especializadas.

$\mathrm{O} \S 6^{\circ}$ do art. 13, finalmente, reporta-se ao procedimento penal cabivel e à sua instauração. O Ministério Público da União ou dos Estados terá legitimidade para propor ação de responsabilidade civil e criminal por danos causados ao homem, aos animais, às plantas e ao meio ambiente, em face do descumprimento da Lei n. 8.974/95. Equivocou-se o legislador em referir-se exclusivamente à persecução criminal nas hipóteses de dano, mormente num diploma em que os tipos penais são, por excelência, de perigo abstrato (ou seja, não há "dano" exceto nas formas qualificadas). Mas, a despeito da impropriedade, compreende-se que a legitimidade processual ativa seja sempre do Ministério Público, independentemente de representação ou requisição (portanto, os delitos do art. 13 desafiam ação penal pública incondicionada), tanto para os crimes de dano quanto para os crimes de perigo. Agirá "in tese" o Ministério Público Federal, e não o Estadual, quando forem interessadas a União (na figura da CTNBio), entidade 
autárquica ou empresa pública federal, na condição de assistentes da acusação (art. 109, I, da Constituição Federal, c/c art. 268 do Código de Processo Penal); em ações penais públicas incondicionadas, a União e suas autarquias ou empresas públicas não podem assumir o papel de autoras, rés ou opoentes. Poderia agir o "parquet" federal, outrossim, quando os resultados virtuais ou efetivos do dano ambiental alcançassem o território de mais de um Estado-membro. ${ }^{41}$ No mais, remanesce a atribuição residual do Ministério Público Estadual. Em matéria penal, não se admite o litisconsórcio ativo entre Ministérios Públicos preconizado por Hugo Nigro Mazzilli para as ações civis públicas. ${ }^{42}$

IV Conclusão.

Este trabalho colige, tão somente, considerações preliminares sobre o tema; não tem, por conseguinte, o propósito de ser exaustivo. Empresas atuantes no país - mormente transnacionais - insistirão em introduzir culturas transgênicas e com seu produto invadir o mercado consumidor interno (até como imposição da economia globalizada, que exige níveis crescentes de competitividade como garantia de sobrevida às empresas subsidiadas de outrora); o Poder Judiciário, por seu turno, começa a resolver, ainda que incipientemente, litígios dessa ordem. Nesse passo, os debates sobre a transgênese tendem a se trasladar rapidamente do mundo da técnica - seara própria das engenharias genética e agronômica — para o mundo da ética nesse incluso o Direito. Sobrevindas, como decerto sobrevirão, novas elucubrações doutrinárias e decisões judiciais a respeito, e enriquecido sobremaneira o universo cognitivo dos operadores do Direito, o pensamento jurídico a respeito uniformizarse-á e, paulatinamente, consolidar-se-á. Então, o jurista e o técnico poderão dialogar sem intermediários, buscando ambos, sob os auspícios da Bioética, soluções que

41. Acatamos e adaptamos, nesse particular, as razões de Hugo Nigro Mazzilli ( $A$ Defesa dos Interesses Difusos em Juizo, $7^{\mathrm{a}}$ ed., S. Paulo, Saraiva, 1995, p. 220): "Pela gravidade que ultimamente a lesão a tais interesses [defesa do meio ambiente] tem assumido, já vimos sustentando que seria oportuno cogitar de conferir competência à justiça federal para apreciar e julgar as causas relativas ao meio ambiente quando os resultados do dano ecológico alcançarem o território de mais de um Estado-membro. Tal competência deveria compreender as ações civis ou penais, principais ou cautelares. No tocante às cautelares [e, acresça-se, às açōes penais por crimes de perigo abstrato], a determinação de competência decorreria da fundada probabilidade de que os efeitos de um possível acidente ecológico viessem a atingir mais de um Estado-membro". Mazzilli compreende, todavia, que somente em face de lei infraconstitucional essa regra de competência poderia vingar.

42. Hugo Nigro Mazzilli, op. cit., pp. 266-273. 
convenham à biossegurança e às exigências de mercado; ao Direito e à Economia; à coletividade, às instituições públicas e à empresa; à Justiça, à Política e à Tecnologia. A Ciência não pode vilipendiar os valores éticos da sociedade; mas tampouco podem os guardiões do interesse público, sob o pretexto eterno da prevenção, coarctar o evolver da História. Agora, como antes, a virtude estará na contemporização.

São Paulo, dezembro de 1999.

Bibliografia.

1. Livros, Teses, Jornais e Revistas.

ADAS, Melhem. Panorama Geográfico do Brasil, $2^{\text {a }}$ ed., S. Paulo, Ed. Moderna, 1989.

ALESSI, Renato. Sistema istituzionale del diritto amministrativo italiano, 1960.

ÁLVARES, Walter Tolentino. Introdução ao Direito da Energia Nuclear, S. Paulo, Sugestões Literárias, 1975.

ANTUNES, Paulo de Bessa. Direito Ambiental, Rio de Janeiro, Lumen Juris, 1996.

COSTA JÚNIOR. Paulo José da. Direito Penal Ecológico, Rio de Janeiro, Forense Universitária, 1996.

FOLHA DE S. PAULO de 13.02.99.

FOLHA DE S. PAULO de 22.04.99.

FOLHA DE S. PAULO de 28.04.99.

FRANCO, Alberto Silva. "Genética Humana e Direito" in Revista Bioética, 4 (1): 17-29, 1996.

HOBSBAWN, Eric. Era dos Extremos - O breve século XX (1914-1991), $2^{\mathrm{a}}$ ed., S.Paulo, Companhia das Letras, 1998.

JESUS, Damásio de. Direito Penal, v. 1, 15ª ed., S. Paulo, Saraiva, 1991.

MACHADO, Paulo Affonso Leme. Estudos de Direito Ambiental, S. Paulo, Malheiros, 1994.

MARTINS, Sérgio Pinto. Direito da Seguridade Social, $2^{\mathrm{a}}$ ed., S. Paulo, Atlas, 1993.

MAZZILLI, Hugo Nigro. A Defesa dos Interesses Difusos em Juizo, $7^{\text {a }}$ ed., S. Paulo, 
Saraiva, 1995.

MORAND-DEVILLER, J. Droit de l'environnement, Paris, ESTEM, 1996.

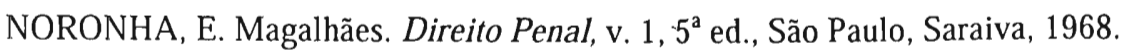

PESSINI, Léo, \& BARCHIFONTAINE, Christian de Paul de (orgs.). Fundamentos da Bioética, S. Paulo, Paulus, 1996.

PRIEUR, Michel. Droit de l'environnement, $3^{\mathrm{a}}$ édition, Paris, Dalloz, 1996.

SANTOS, Maria Celeste Cordeiro Leite dos. O Equilibrio de um Pêndulo. Bioética e a Lei: Implicações Médico-Legais, tese apresentada ao Concurso de Professor Titular do Departamento de Medicina Forense e Criminologia da FDUSP S. Paulo, 1997.

VARELLA, Marcelo Dias, \& BORGES, Roxana Cardoso B. (orgs.). O Novo em Direito Ambiental, Belo Horizonte, Del Rey, 1998.

\section{Normas.}

Código Civil.

Código Penal.

Conselho Nacional de Saúde. Resolução n. 196/96 ("Diretrizes e Normas Regulamentadoras de Pesquisas Envolvendo Seres Humanos").

Constituição Federal de 1988.

CTNBio. Instrução Normativa n. 08/97 ("Instrução Governamental sobre Manipulação Genética e Clonagem em Seres Humanos").

CTNBio. Instrução Normativa n. 09/97 ("Normas sobre Intervenção Genética em Seres Humanos").

Declaração do Rio de Janeiro sobre Meio Ambiente e Desenvolvimento (Conferência das Nações Unidas sobre Meio Ambiente e Desenvolvimento, 1992).

Decreto n. 1.520/95.

Lei de Introdução ao Código Civil.

Lei n. 6.938/81.

Lei n. 8.974/95.

Lei n. 9.605/98. 